\title{
Exploring electronic -loyalty antecedents in Egyptian commercial banks; Electronic customer relationship management and banking electronic satisfaction
}

\author{
Hadeer Helal M. Rashwan \\ Abdelaty L. M. Mansi \\ Heba E. Hassan \\ Faculty of commerce, Suez University, Egypt
}

\begin{abstract}
Keywords
Electronic Customer Relationship Management, Electronic Communication Channels, Customization Strategy, intentions to repeat electronic transactions, positive words of mouth, Electronic Banking Satisfaction.
\end{abstract}

\begin{abstract}
Identifying factors that influence customer's e-loyalty is paramount for commercial banks to develop successful marketing strategies to form a broad base of customers that practice online transaction. So, this study aimed to investigate the impact of Electronic Customer Relationship Management (E-CRM) dimensions (customization strategy, electronic communication channels) on Electronic loyalty of customers through electronic banking satisfaction as a mediator Variable in Egyptian commercial banks. A quantitative approach was followed using questionnaire, the sample consisted of 370 customers practicing online transaction. Data were collected from a convenience sample; a questionnaire was pretested using confirmatory factor analysis to assess the measurement model. Structural equation modeling was performed to examine the relation between latent variables. The study concluded: that the changing customer dynamic in Egyptian commercial banks is being driven by the move away from physical bank branches a phenomenon drive by the need to reduce costs, a significant correlation between the of E-CRM and intention to repeat electronic transactions and providing positive words of mouth, thus achieving electronic loyalty, and the electronic banking satisfaction is not a mediator in influencing the relationship between E-CRM dimensions and providing positive Words of mouth and intention to Repeat electronic transactions. So, managers will likely increase E- loyalty of customers by improving contact with customers and balancing their needs and Services customization to them, predisposing positively customer's attitudes towards the banks.
\end{abstract}

Corresponding author: Hadeer Helal M. Rashwan

Email addresses for the corresponding author: hadeerhelal2020@gmail.com

First submission received: $8^{\text {th }}$ April 2020

Revised submission received: $20^{\text {th }}$ April 2020

Accepted: 23rd April 2020

\section{Introduction}

Electronic customer relationship management helps to improve the relationship between the banks and their customers in order to achieve customer satisfaction and loyalty, thus increase profits (AbuShanab and Anagreh, 2015). In addition to reducing costs because of decreasing the cycle times of implementing activities and increasing marketing knowledge, For customers, e-CRM improves customer service through enhancing the efficiency of customers' processes and bringing down the transaction costs for customers (Azila and Noor, 2011) In terms of speed and accuracy in the processing of banking transactions, convenience in electronic dealing with the bank, reduced response time and the availability of the latest online banking Information (Dhingra and Dhingra 2013).

Electronic Customer relationship management is a comprehensive marketing strategy that integrates technology, people and processes for attracting and retaining customers through Electronic Communication Channels such as the mobile phones and internet (Azila and Noor, 2012).and Banks use electronic communication channels such as SMS, online banking, free numbers, online reminders, bank account updates to speed up transactions with customers, and keep in contact with them 24 hours a day, seven days a week (Abu-shanab etal. 2015). Since customer loyalty is the key, particularly in the highly

www.jbrmr.com A Journal of the Centre for Business \& Economic Research (CBER) 
competitive commercial banking environment (Mang' unyi, Khabala and Govender, 2017), So Commercial banks are shifting their business strategies from product-oriented to being customer-oriented. This enables banks to achieve higher returns on investment and provide investment opportunities by understanding their customer desires (El Essawi and Abd El Aziz, 2012).

The relationship between e-CRM and customer loyalty lead to the more customers are satisfied, they repurchase and providing positive word-of-mouth about the services (Azila et al. 2012). and these goals will be realized through the concentration of commercial banks on individual customers and customize of services to them in order to establish a long-term relationship, and eliminate the obstacles and damage that prevent the provision of added value to the customer, these goals will be realized in the digital environment by using the E-CRM (Farnad and Afghah, 2017), where E-CRM works to achieve Eloyalty of customer in commercial banks (Noor, 2018), by making customers receive exclusive personal services (Alim and Ozuem, 2014; Harrigan, Ramsey and Ibbotson,2012), access to relevant information (Michal and Stverka, 2001), Quickly and appropriately response to customer requests (Mogharabi, Akbarabadi, Mirnezhad and Kariznoee, 2014).

The customization dimension can be also understood as refers to the degree to which information or service to meet the needs of the individual customer (Lee, 2005). This dimension has become an essential part of online service quality (Zeithaml, Parasuraman and Malhotra, 2002). The concept of customization divided into four parts in an e-commerce system: understanding the specific desires of customers, preferences, and information of the products modification, personal attention (Kassim and Abdullah, 2010). And customers who have a personal relationship with the bank are more satisfied and loyal (Ski, 2016). therefore Banks should look for strong strategies for excellence in banking services to overcome competitors, enhance customer confidence in the Bank's ability to meet their needs, and persuade them to move from Traditional banking services to electronic banking services, and customer access to loyalty stage to the service provided by the Bank (Al-Hawary and Hussien, 2017).

Moreover, Technological advances have increased opportunities for customers, making them more demanding and aware and thus increasing their bargaining power (Abu-Shanab et al. 2015). Thus, Customization and Responsiveness may not be alone enough to improve customer loyalty (Kassim et al. 2010). Consequently, e-customer satisfaction has been identified as an important factor to achieve Eloyalty of customer (Amin, 2016). Additionally, Mang'unyi, Khabala and Govender (2018) explain that there is a significant relationship between the dimensions of e-CRM (Communication platforms, Customization) and customer loyalty. This situation Make banks do more marketing efforts and improve Internet banking technologies for upgrading the relationship with customers (Amin, 2016). In the light of the aforementioned, this paper explores how Egyptian commercial banks may use e-CRM dimensions (Electronic Communication Channels, Customization Strategy) to achieve customer E-loyalty through customer satisfaction for electronic banking services?

\section{Literature review}

\subsection{Electronic communication channels and their impact on electronic loyalty}

E-CRM has helped commercial banks to interaction with customers through E-mail, banking Service Automation and Call center which leads to increased customer e-loyalty (Miremadi, Ghalamakri and Ramezani, 2012). So E-CRM has become a more Interactive communication tool and relationship creating platform with customers (Lam, Cheung and Lau, 2013), When banks applies e-CRM initiatives, their customers expect accurate, more complete, and up-to-date information through using communication channels, ability to contact their banks from anywhere through more various channels (Abu-shanab et al. 2015), So banks compete for applies of advanced electronic channels to meet customers' needs after understanding their desires and determine what is the most and favorable for them (Keshvari, 2012). Because Poor communication between banks and customers leads to the inability of banks to interact well with customers, thus, it is difficult to understand the needs of customers who prefer to electronic transactions with the bank (Poon, 2008).

The business press abounds with articles concerning of e-CRM (Sivaraks, Krairit and Tang 2011; Zeithaml et al. 2002; Khaligh, Miremadi and Aminilari, 2012; Levy, 2014; Alim et al. 2014; Lam et al. 2013) suggest that there a relation between Electronic communication channels and E- loyalty. Where Sivaraks 
et al. (2011) believed that when an organization depended on electronic communication channels such as the Web, e-mail, fax and phone, its ability to measure, manage and develop customer relationships increases. That is not unlike with Khaligh et al. (2012) they proved that electronic communication channels (mobile phone applications, e-mail, use of ATMs) as one of the dimensions of E-CRM affect the loyalty of customers mobile phone companies in Iran. And when the internet banking fails to provide communication channels which the customers need, they will not be developing good relationship with their customers (Levy, 2014). Because personal communication works to improve the relationship with customers (Romano and Fjermestad, 2003). Similarly, the weakness of electronic communication channels in terms of making inaccurate or inflated promises about the website generates negative perceptions of customers about the quality of e-service and hence low intentions to revisit the site again (Zeithaml et al. 2002). Even more important is Alim et al. (2014) stresses that contact interactivity is a key feature of ECRM that affects customer loyalty in UK mobile phone companies. And disagreed with them Kassim et al. (2010) who proved that responsiveness to customers needs does not affect customer E-satisfaction. And Rahimiparvar, (2012) believes that there is a weak relation between Electronic communication channels and customer loyalty for online shopping in Thailand, This may be due to the continued pressure on the server led to slow down the loading of programs and applications, thus increasing the effort exerted by the customers to completing transactions, which negatively affected their satisfaction and then E-loyalty.

The Literature differed in determined the dimensions of the electronic communication channels affecting on the E-loyalty of customers. This may be due to the difference in the nature of the research problem and the different scope of application. Where some studies have been applied on the Sample of customers of mobile phone companies such as (Khaligh et al. 2012) (Sunny and Abolaji, 2016) and others have been applied to the banks such as (Miremadi et al. 2012) Which rely more on web-based communication channels, SMS, email, fax to interact with customers and receive suggestions and complaints. While study of Hosseinianzadeh (2015); Pensiri, (2011) was adopted in measuring the dimensions of electronic communication channels on the technology used. Where the scope of application was the managers of different departments and branches, especially IT managers, which required measuring the compatibility of the technology used with the objectives of the work and making sure the extent of availability an effective infrastructure for managing electronic communication channels. Mogharabi et al. (2014) has relied on the measurement the electronic communication channels (Web Effectiveness and personal communications systems). We show the measurement method is appropriate to a certain extent because this study was applied to online shopping customers who have the ability to determine effectiveness of these channels in the interaction with them.

According to studies conducted by different researchers (Miremadi et al. 2012; Zeithaml et al. 2002; Liu, Tseng, Chuang and Huang, 2012; Sunny et al. 2016; Lam et al. 2013) Researchers differed in determining electronic communication channels is the most effective in influencing the E-loyalty of customers. Where Miremadi et al. (2012) found that E-mail is the most communication channel used by banks to interact with customers. Where the rapid response to the website through hot e-mail was a key indicator of the quality of service provided through the Internet (Zeithaml et al. 2002). Similarly Liu et al. (2012) found E-mail and online banking services are the most effective communication channels compared to ATM in communicating with customers, because the ATM platform is designed In a different way from other banks, which cooperate with different operators, that Led to inability customers to access To service When they were in desperate need of it, in addition to the low number of these channels the customer became use other alternatives (low loyalty). While (Belás, Chochol'áková and Gabčová (2015) emphasized that an effective communication and developed network of ATMs are the most important determinant of customer satisfaction. And disagreed with these previous findings Sunny et al. (2016) who found that there are no significant differences between the dimensions of electronic communication channels (mobile phone applications, e-mail, communications via internet) used to achieving loyalty For customers in three leading telecommunications companies in Nigeria, we see This is probably due to the desire of telecom companies Maintain the competitive level and to provide a comparable services level. We concluded from the previous presentation that electronic communication channels are the most important dimensions of E- CRM that affects the electronic loyalty, and that electronic communication channels dimensions include e-mail, internet banking, and ATMs. Therefore, in this study it is hypothesized that: 
H1 There is a significant relationship between the electronic communication channels as one of the dimensions of E- CRM and E-loyalty of customer.

This hypothesis is divided into the following sub- hypothesizes:

H1/1 There is a significant relationship between the electronic communication channels as one of the dimensions of the E-CRM and intentions to repeat electronic dealing.

$\mathrm{H} 1 / 2$ There is a significant relationship between the electronic communication channels as one of the dimensions of E-CRM and providing customers with positive words of mouth for others.

\subsection{Customization and its impact on e-loyalty}

Compliance with the needs and requirements of different customers is at the heart of the researchers' attention as they represent important marketing variables for banks, especially those operating in more competitive markets. Zeithaml et al. (2002) Emphasized that Customization is a feature in which desires differ among customers. And conclude in his study customize of information and services affects the perceptions of customers of the quality of e-service, which is reflected in the intentions of customers to repeat e-dealing and provide positive recommendations to others about e-dealing. Effective E-CRM is concerned with different individual preferences for customers (males and females) in order to create E-loyalty of customers (Mang'unyi et al. 2018). Dhingra et al. (2013) Confirmed that the Dimensions of e-CRM that achieve customer satisfaction is enhance one-on-one relationship between banks and customers. And satisfaction is critical to loyalty and must be considered in all electronic service relationships (Mang'unyi et al. 2017). strategic role of E-CRM in banks is Meet the diversity of needs of different customers(Abu-shanab et al. 2015).because personalized web pages, detailed information that provides transparency, customer assistance, and individually Designed services (Rialti, Zollo, Pellegrini, and Ciappei, 2017). These increase the Customer's trust, and their satisfaction (Faraoni, Rialti, Zollo and Pellicelli, 2018).

Electronic Customer Relationship Management (CRM) has led to the emergence of new market structures and different categories of customers, so the way business is done and how relationships are created and managed with customers will change (Romano et al. 2003). Where Focusing on the client and having a personal relationship with the customer leads to a stronger relationship. Miremadi et al. (2012) suggested that E-CRM enables banks to provide one to one marketing or Personalized services which helps to establish long-term relationships with customers. Peikari (2010) who concluded that the formulation of E-CRM strategy affects the improvement customer relationship, where the strategy is focused on what customers want (such as product Customization, selection Appropriate of communication channels, and facilitation of the site map). While Ismail and Safa, (2014) emphasized that an Organizational factor which include customer segmentation and product Customization affect customer loyalty with taking e-satisfaction as a mediator variable. Mang' unyi et al. $(2017,2018)$ confirmed that Customization is the most dimensions of E-CRM which effects on customer loyalty. We believe that this is due to the fact that this study was applied on the Sample of customer of commercial banks in Kenya. And Commercial banks are characterized by effective customization because they offer multiple and diversify services. And customize these services to specific customers, leads to reducing the pressure on the server and branches which provides convenience to customers and profitability of the bank.

The customization strategy has come into the spotlight when commercial banks became operate in more competitive markets. So Alim et al. (2014) Prove that the Customization has a significant impact on satisfaction and customer loyalty, because mobile phone companies in the UK provides special offers to the most valuable customers only, which improves their satisfaction and encourage them to renew the intention to repeat e-dealing. Personalization makes customers feel convenience, and banks can get information about their customers, and when the banks knowing more about variety segments of customers, makes customization efficiently utilize Programs advertising and promotion (Abu-shanab et al. 2015). Palmer (2002) proved that There is a significant associated between customization and website success. While Rahimiparvar, (2012) concluded that there is a moderate correlation between Personalization and customer loyalty through customer satisfaction.

While other studies have found different results with the previous results for example (Amin, 2016; Kassim et al. 2010; Faraoni et al. 2018; Saini and kumar, 2015; Hosseinianzadeh, 2015; Liu et al. 2014) where Amin (2016) proved that providing personal needs to customers does not positively affect the e- 
loyalty of customers. Faraoni et al. (2018) proved that there is no significant relationship between relational investment with customers and e-satisfaction. And Kassim et al. (2010) proved that Customization of services does not affect customer E-satisfaction. Because of lack of attention to the needs of personal customers and the low level of service Customized to them via the Internet. While Liu et al. (2014) confirmed that dimension of knowledge of customers does not affect customer satisfaction with product or service as well as customer loyalty. And disagreed with him Hosseinianzadeh, (2015), who believes that strategies of Customization of relationships are the least important factors when implementing Electronic customer relationship management. While Saini et al. (2015) confirmed that there is not a significant relationship between personalized offers and consumers satisfaction toward online shopping compared to the Convenience and security expected.

We find that the results reached by (Saini et al. 2015) is a logical result because the customer seeks from the electronic deal to protect privacy of transactions and provide convenience in the use of the website. We also believe that there is a weak relationship or no relationship between the strategy of customization and customer loyalty may be due to the Difficult to understand the needs and desires of customers and their expected value. Which made the customization strategy not focused on the Actual customer needs, thus the Customization strategy does not affect satisfaction of customer and then their loyalty.

We conclude from the previous presentation that the Customization strategy is one of the dimensions of the E- CRM that affects the electronic loyalty, and that the Customization strategy dimensions include the (Customization of relationships and Customization of services). Therefore, the next hypothesis is assumed:

H2 There is a significant relationship between the Customization strategy as one of the dimensions of ECRM and E-loyalty of customer.

This hypothesis is divided into the following sub- hypothesis:

H2/1 There is a significant relationship between the Customization strategy as one of the dimensions of E-CRM and intentions to repeat electronic dealing.

$\mathrm{H} 2 / 2$ There is a significant relationship between the Customization strategy as one of the dimensions of E-CRM and Provide customers with positive words of mouth for others.

\subsection{Electronic satisfaction as a mediator variable between E-CRM dimensions and E-loyalty}

Customer satisfaction is a complex process and forms habits of consumers and their attitudes of customers towards a bank (Belás et al. 2015). E-CRM is a management strategy that includes marketing with information technology to attract customers' satisfaction (Rao, 2013). Customer satisfaction with eservices helps to develop the behavioral side of customers in terms of the intention of repeat e-dealing, and the emotional side in terms of providing customers with positive words of mouth to others. Previous research has confirmed that there are various Determinants of Electronic Banking Satisfaction (Kassim et al. 2010). Where Amin (2016) suggests that Personal Need, Site organization, and Efficiency of websites are the driver of e-customer satisfaction, Valvi and West (2013) proved that Perceived Value, Convenience Motivation, have significant impact on satisfaction of customer online. Dimensions of e-satisfaction such as (Internet accessibility, network setup and previous experience of perceived IT usage with the bank) explains the relation between e-CRM and loyalty (Mang' unyi et al. 2017).

There are some studies that proved the relationship between e-CRM and e-loyalty via E-Satisfaction such as (Rahimiparvar, 2012; Zatalini and Pamungkas, 2017; Alhaiou, 2011; Farhadi, Ghartemani, Ghartemani and Wastegany, 2012) Where Alhaiou (2011) confirmed that The dimensions of electronic CRM, which include (website design, time delivery and demand tracking) have a significant relationship with electronic loyalty through electronic satisfaction in mobile phone companies in Britain. While Rahimiparvar (2012) concluded that the dimensions of the electronic CRM, which include (customization and electronic communication channels) have a significant relationship with e-loyalty through electronic satisfaction for three international sites for online shopping in Thailand. Zatalini et al. (2017) emphasized that the dimensions of E-CRM, which include (access to information and services and the availability of security and trust in the website) have a significant relationship with e-loyalty through electronic satisfaction of online shopping customers in Indonesia. On the other side Amin (2016) was proved that 
internet service quality in terms of Meet the personal needs of customers has an indirect effect on e-loyalty of customers via e-satisfaction of customers in the banking sector in Malaysia.

While (Khan and Khawaja, 2013; Mang'unyi et al. 2018; Shastri, Rathore and Sharma, 2018; Mulyono and Situmorang, 2018) proved that The direct relationship between the dimensions of e-CRM and e-loyalty is stronger than the indirect relationship between them Through electronic satisfaction, where Shastri et al. (2018)Found The dimensions of the E-CRM, which include (accuracy of information, trust in the website and the simplicity of e-transactions) have a significant relationship with the intentions of repeat e-dealing and provides words of mouth for others about E-dealing with commercial banks in India. While Mulyono et al. (2018) confirmed that The dimensions of E-CRM, which include (the effectiveness of electronic communication channels and the provision of specialized services to customers) have a positive and important impact on the Intentions to repeat the electronic deal and defend the organization in front of other customers and provide positive words of mouth for them about online transactions in Indonesia. While Mang'unyi et al. (2018) confirmed that Customer satisfaction does not mediate the relationship between the dimensions of e-CRM (Customized promotions, Communications) and customer loyalty.

On the other side literature proved that e-satisfaction is the most influential factor on the relation between the dimensions of E-CRM and e-loyalty, where Farhadi et al. (2012) found that customer satisfaction affects the relationship between the dimensions of E-CRM and E-loyalty more than the empathy that attracts customers. While Mulyono et al. (2018) found that E-satisfaction affects the relationship between the dimensions of E-CRM and E-loyalty more than previous experiences of e-dealing customers. While the study Rosário (2015) found that E- satisfaction effects on E-loyalty of customers more than choose a brand. Valvi et al. (2013) found that E- satisfaction affects more than E-trust on Eloyalty of customers. While Peikari (2010) Found Customer satisfaction with e-commerce affects e-loyalty more than the impact of security policy and the provision of technological protection. Therefore, in this study it is hypothesized that: -

H3: Electronic satisfaction as a mediator variable between the dimensions of E-CRM and E-loyalty." This hypothesis is divided into the following four sub- hypothesizes:

$\mathrm{H} 3 / 1$ : Electronic satisfaction as a mediator variable between the electronic communication channels and the intention to repeat e-dealing.

H3/2: Electronic satisfaction as a mediator variable between electronic communication channels and Provide customers with positive words of mouth for others.

$\mathrm{H} 3 / 3$ : Electronic satisfaction as a mediator variable between the Customization strategy and the intention to repeat e-dealing.

H3/4: Electronic satisfaction as a mediator variable between Customization strategy and Provide customers with positive words of mouth for others.

Although the framework presented in this section (see Figure 1) shares the elements of ESatisfaction and Customization, Electronic communication cannel models and their relationships with customer E-loyalty in the literature, this one differs from the current literature in two aspects. First, this study seeks to explain how customer e-loyalty may be demonstrated separately through emotional loyalty such as Provide customers with positive words of mouth for others and behavioral loyalty (intention to repeat e-dealing and preferring the website). Second, the framework seeks to explain how electronic communication channels and customization strategy effect on Provide customers with positive words of mouth for others and intention to repeat e-dealing through the E-satisfaction, and these effects are barely shown in other models. This inclusion is justified because this is the main focus of this research as discussed above.

\section{Methodology}

This research uses structure equation modeling (SEM) to empirically test the proposed conceptual model (Arbuckle, 2013), Figure 1 illustrates The Proposed research framework of the study. 


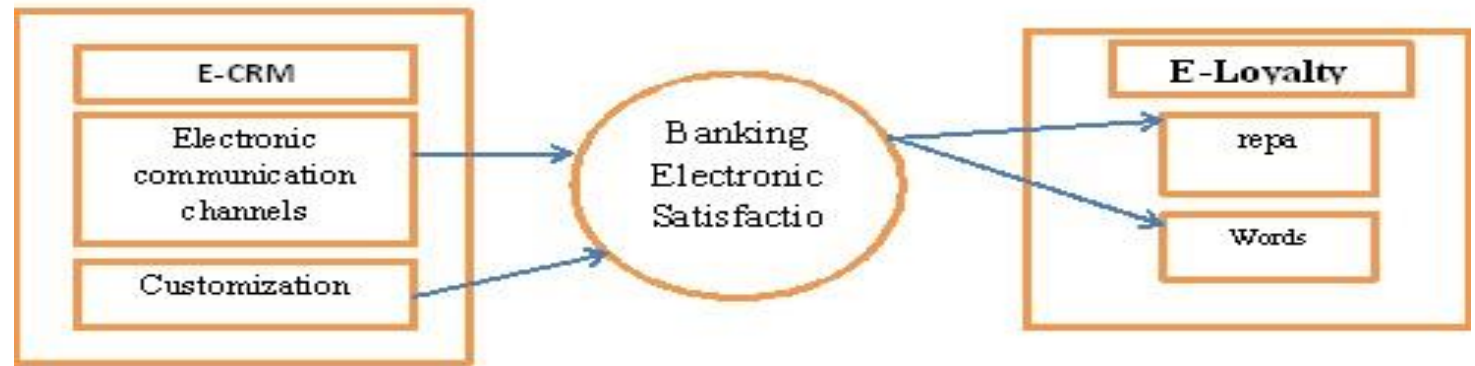

Figure 1. Proposed research framework

Notes: E-CRM=Electronic customer relationship management, repa= intentions to repeat e-dealing., Words $=$ words of mouth.

\subsection{The questionnaire designs}

In the survey, consideration should be given to having at least three items of each construct to ensure internal reliability (Cook, Hepworth, Wall, and Warr, 1981). The content of the questionnaire (clarity of formulation and meaning) was verified by ten university professors who specialize in marketing. Then, a pilot-test was conducted of 30 banks customers who prefer electronic dealing to improve the structure and content of the questionnaire. The five-point Likert scale was used to measure study dimensions from "Strongly Disagree" (1) to "Strongly Agree" (5). A total of 384 questionnaires were distributed and 370 were returned. Six questionnaires were considered invalid because customers did not complete the answer. According to the characteristics of the sample, Males account for $65.6 \%$ and Females $34.3 \%$ percent of the online banking customers. It is a logical result where the contribution of women to the labor force reached $20.9 \%$ of the total labor force compared to $79.1 \%$ for men, according to the report of the Central Agency for Public Mobilization and Statistics year 2019. Interestingly, most of customers were in the age group 30-40 years old (80.8\% total respondents). In the context of e-banking, the younger generation favors the use of online banking compared to older age category (30-40 years above). The number of years online dealing with commercial banks websites ranges between (4 years to 6 years). Customers with the highest qualifications are the most prefer electronic dealing with the bank. Each variable consisted of multi-items based on scales used in previous literature, Electronic communication channels was measured using tool (Ribbink, van Riel, Liljander and Streukens 2004; Ocker and Mudambi, 2002; Abu-Shanab et al. 2015; Al-Hawary et al. 2017; Rao, 2013).The customizing strategy was based on (Herington and Weaven, 2009; Ho and Lin, 2010). Banking Electronic Satisfaction (six related items) the measurement was based on (Herington et al. 2009; Ribbink et al. 2004), E- loyalty (ten related items) included measures from a scale by (Ribbink et al. 2004; Gremler, 1995; Zeithaml, Berry and Parasuraman, 1996; Ramseook and Naidoo, 2011).

\subsection{Sampling and data collection}

Data were collected by using an organized questionnaire to measurement study variables. A convenience sampling method was used in data collection. The researchers distributed the questionnaires by themselves to the customers inside the bank. Customers were selected among those customers who prefer online banking transaction. Diverse controls were put to ensure credibility of the survey. The purpose of the study was explained, and that the respondents have experienced with online banking transaction. This study was conducted in three different cities in Egypt during January 2019 - April 2019 period. The commercial banks were chosen because they represent one of the services sectors which contribute to the promoting of economic growth in Egypt.

\subsection{Measurement model}

The measurement elements used in this study were based on measurements that proved reliable and Credibility in the previous literature. Confirmatory factor analysis (CFA) model for the structural model of the study was estimated to test the measurement model using AMOS 24. The first-order CFA result explained that the goodness of-fit was satisfied. The NFI value is 0.96 , RMSEA value 0.02 , and CFI value 0.99. To test the reliability of Electronic Communication Channels, Customization Strategy, e- 
banking satisfaction, intention to repeat e-dealing and Provide customers with positive words of mouth., the (Cronbach's a) coefficient was estimated. The coefficient a exceeded the minimum standard of 0.70 (Nunnally, 1979), which showed a good estimate of internal consistency. The (Cronbach's a) achieved acceptable value 0.89 and 0.93 respectively for the Electronic Customer Relationship Management dimensions (Electronic Communication Channels and Customization Strategy). Meanwhile, e-banking satisfaction, intention to repeat e-dealing and providing customers with positive words of mouth. The coefficient a obtained values achieved acceptable values (0.91 and 0.94, .95 respectively). The factor loadings were used to assess the convergent validity for each variable (Hair, Black, Babin, and Anderson, 2010). Convergent validity was achieved when the factor loadings are greater than 0.5 and the AVE is greater than 0.5 (Fornell and Larcker, 1981), composite reliability greater than 0.7 (Hair et al. 2010). The findings show that factors loading ranged from 0.74 to 0.99 and exceeded the recommended level of 0.50 . the convergent validity for each variable(Electronic Communication Channels, Customization Strategy, ebanking satisfaction, intention to repeat e-dealing and Provide customers with positive words of mouth) were estimated, therefore providing additional evidence of construct validity for all the variables in this study (Hair et al. 2010). In addition, average variance extracted (AVE) was established for assessing discriminant validity for the structural model (Hair et al. 2010), and the AVE ranged from (0.71 to 0.85).

\begin{tabular}{|c|c|c|c|c|c|}
\hline & EFA & CFA & CR & $\begin{array}{c}\text { Cronbach's } \\
\text { alpha }\end{array}$ & AVE \\
\hline canl1 & .86 & .79 & & & \\
\hline canl2 & .84 & .78 & & & \\
\hline canl3 & .87 & .83 & & & \\
\hline canl4 & .94 & .96 & & & \\
\hline Canl & & & 90. & .89 & .71 \\
\hline spec1 & .91 & .88 & & & \\
\hline cpec2 & .91 & .89 & & & \\
\hline spec3 & .92 & .89 & & & \\
\hline spec4 & .89 & .84 & & & \\
\hline Spec & & & 93. & .93 & .77 \\
\hline sati1 & .90 & .88 & & & \\
\hline sati2 & .91 & .88 & & & \\
\hline sati3 & .89 & .86 & & & \\
\hline sati4 & .88 & .83 & & & \\
\hline sati & & & 92. & .91 & .75 \\
\hline repa1 & .85 & .81 & & & \\
\hline repa2 & .87 & .83 & & & \\
\hline
\end{tabular}




\begin{tabular}{llllll}
\hline repa3 & .81 & .74 & & & \\
repa4 & .91 & .89 & & & \\
repa5 & .96 & .99 & & .73 \\
repa & & & 93. & & \\
words1 & .95 & .94 & & & \\
words2 & .95 & .92 & & & \\
words3 & .92 & .89 & & \\
words4 & .94 & .94 & & .85 \\
words & & & 96. & .95
\end{tabular}

Table 1: exploratory factor analysis, Confirmed Factor Analysis, Composite Reliability, Cronbach's Alpha, and Average Variance Extracted

canl= Electronic Communication Channels, spec=Customization Strategy, sati= banking Electronic Satisfaction, repa $=$ intention to repeat e-dealing, Words= Provide customers with positive words of mouth. AVE: Average Variance Extracted; CR: Composite Reliability.

\section{Data analysis}

The data analysis process involves two stages, (Anderson and Gerbing 1988). First, the measurement model is analyzed, the collection of items of each construct must well measure the construct related to them, that is ensure the accuracy of the indicators. In the second stage of the model, the structural relationships between the Latent variables are investigated, and then the hypotheses are tested.

\subsection{Testing of hypotheses}

Figure (2) the structural model of the study

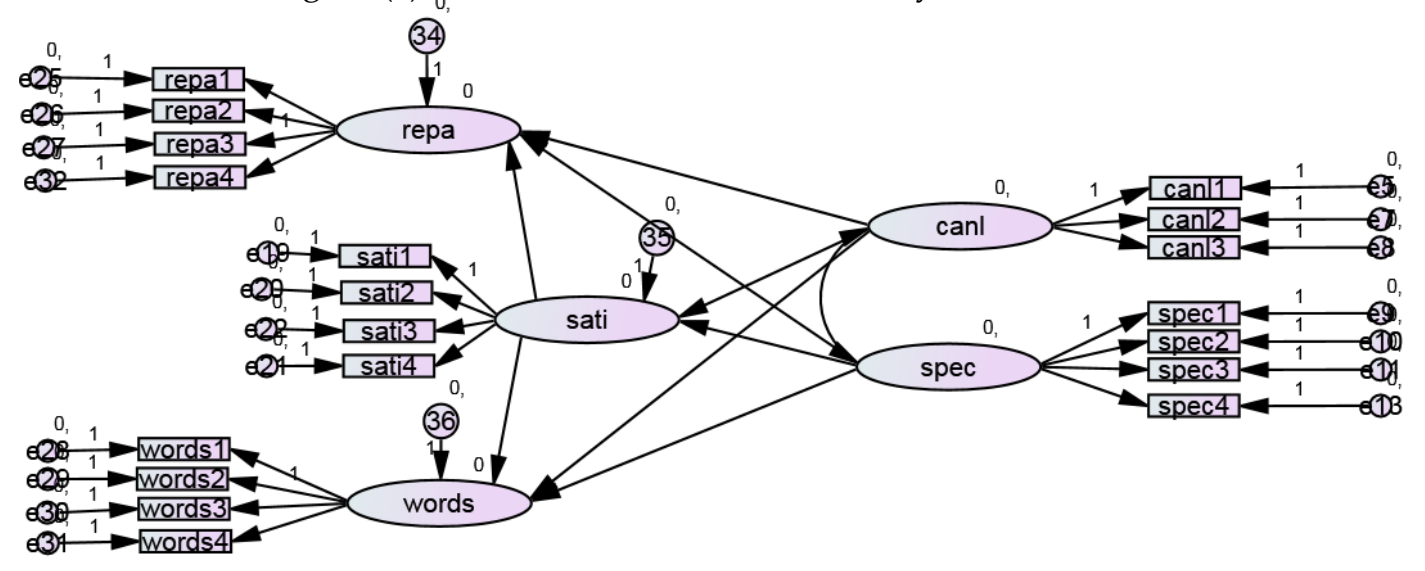




\begin{tabular}{lll} 
Measures & \multicolumn{1}{c}{ Fit Indices } & Threshold Values \\
\hline CMIN/DF & 1.2 & Less than 3 \\
CFI & 0.99 & 0.90 and above \\
IFI & 0.99 & 0.90 and above \\
RFI & 0.96 & 0.90 and above \\
TLI & 0.99 & 0.90 and above \\
NFI & 0.96 & 0.90 and above \\
RMSEA & 0.025 & 0.90 and above \\
\hline
\end{tabular}

Table 3 Results of the quality indicators of conformity of the structural model of the study (model fit)

Regression Weights: (Group number 1 - Default model)

\begin{tabular}{|c|c|c|c|c|c|c|}
\hline & & Estimate & S.E. & C.R. & $\mathrm{P}$ & Label \\
\hline repa & canl & .078 & .036 & 2.137 & .033 & \\
\hline words & $<--$ spec & .329 & .107 & 3.074 & .002 & \\
\hline words & <--- canl & .036 & .085 & .421 & .674 & \\
\hline repa & $<---\quad$ spec & .009 & .045 & 195 & .845 & \\
\hline
\end{tabular}

Table 4 Regression Weights: (Group number 1 - Default model)

The results shown in the previous table can test the study hypothesis:

The hypothesis(H1/1) was supported, as $\mathrm{CR}=2.137$ (i.e. more than1. 96) that indicate to the effect of independent variable on the dependent variable is significant, and (Estimate $=.078$ ) with a positive sign indicating there is a positive relationship between the electronic communication channels and the intentions of E-dealing with the bank, the greater of the level of availability of electronic communication channels by one, Increasing the intentions of dealing with the bank by (.078) and the value of $(\mathrm{P}=.033)$ This indicates the relationship between the electronic communication channels and intentions of repeated e-dealing is significant.

The hypothesis $(\mathrm{H} 1 / 2)$ was not supported, as $\mathrm{CR}=.421$ (i.e. less than 1.96) that indicate to the effect of independent variable on the dependent variable is not significant, and the value of $(P=.674)$ this indicates the relationship between the electronic communication channels and provide customers with positive words of mouth to others about dealing with the bank is not significant.

The hypothesis $(\mathrm{H} 2 / 1)$ was not supported, as $\mathrm{CR}=.195$ (i.e. less than 1. 96) that indicate to the effect of independent variable on the dependent variable is not significant, and the value of $(\mathrm{P}=.845)$ this indicates the relationship between the customization strategy followed by the bank with customers and intentions of repeated e-dealing is not significant.

The hypothesis(H2/2) was supported, because a value of $(\mathrm{CR}=3.074)$, which is more than $(1.96)$ that indicate to the effect of independent variable on the dependent variable is significant, and (Estimate = .329) with a positive sign indicating that there is positive relationship between customization strategy, and providing positive words of mouth, the more customization in website by one, the more customers offer positive words of mouth to others about the electronic deal with the bank( by .329), and the value of $(\mathrm{P}=.002)$ Indicates the relationship between the customization strategy, and provide customers with positive words of mouth to others about dealing with the bank is significant.

\section{Standardized Direct Effect and Standardized Indirect Effect by Using the Bootstrap method}

To test hypothesis H3, Mediator variable test through Bootstrap method 


\begin{tabular}{|c|c|c|c|c|c|c|c|}
\hline Independent & Mediator & Dependent & $\begin{array}{c}\text { Direct path } \\
\text { coefficient } \\
\text { value }\end{array}$ & Significant. & $\begin{array}{c}\text { Indirect path } \\
\text { coefficient } \\
\text { value }\end{array}$ & $\begin{array}{l}\text { Significant. } \\
\text { (2-tailed) }\end{array}$ & $\begin{array}{c}\text { Total path } \\
\text { coefficient } \\
\text { value }\end{array}$ \\
\hline $\begin{array}{r}\text { electronic } \\
\text { communication } \\
\text { channels }\end{array}$ & $\begin{array}{r}\text { E-banking } \\
\text { Satisfaction }\end{array}$ & $\begin{array}{l}\text { intention } \\
\text { repeat E- } \\
\text { dealing }\end{array}$ & .078 & .033 & .003 & .217 & .081 \\
\hline $\begin{array}{r}\text { customization } \\
\text { strategy }\end{array}$ & $\begin{array}{l}\text { E-banking } \\
\text { Satisfaction }\end{array}$ & $\begin{array}{l}\text { intention } \\
\text { repeat E- } \\
\text { dealing }\end{array}$ & .009 & .845 & -.005 & .146 & .003 \\
\hline
\end{tabular}

Table 5 Results of the direct, indirect and total relationship of the study variables The previous table shows the results of the direct and indirect impact of the dimensions of e-customer relationships and the intentions of repeat e-dealing through the banking Electronic Satisfaction.

The previous table Show that: There is a significant effect between the (electronic communication channels) and the intention repeat E- dealing. Where the value of the beta coefficient was $p=(.033)$. And the relationship between customization strategy and the intentions of repeat E- dealing is not significance, where the value of the beta coefficient was more than $(0.05)$.

Found a direct impact between (electronic communication channels, customization strategy) and intentions of e-dealing. Greater than the indirect effect between (electronic communication channels, customization strategy) and Intentions to repeat e-dealing. Indicating that E-banking Satisfaction does not play the role of mediator in influencing on the relationship between E-CRM dimensions (electronic communication channels, customization strategy) and intention to repeat e-dealing. And thus, reject the sub- hypothesis's (the first and the second) of the third main hypothesis.

\begin{tabular}{|c|c|c|c|c|c|c|c|}
\hline \multicolumn{3}{|c|}{ Variables } & \multirow{2}{*}{$\begin{array}{c}\text { Direct path } \\
\text { coefficient } \\
\text { value }\end{array}$} & \multirow[t]{2}{*}{ Significant. } & \multirow{2}{*}{$\begin{array}{l}\text { Indirect path } \\
\text { coefficient } \\
\text { value }\end{array}$} & \multirow{2}{*}{$\begin{array}{l}\text { Significant. } \\
\text { (2-tailed) }\end{array}$} & \multirow{2}{*}{$\begin{array}{c}\text { Total path } \\
\text { coefficient } \\
\text { value }\end{array}$} \\
\hline Independent & Mediator & dependent & & & & & \\
\hline $\begin{array}{r}\text { electronic } \\
\text { communication } \\
\text { channels }\end{array}$ & $\begin{array}{l}\text { E-banking } \\
\text { Satisfaction }\end{array}$ & $\begin{array}{c}\text { Providing } \\
\text { positive } \\
\text { words of } \\
\text { mouth. }\end{array}$ & .036 & .674 & -.016 & .263 & .020 \\
\hline $\begin{array}{r}\text { Customization } \\
\text { strategy }\end{array}$ & $\begin{array}{l}\text { E-banking } \\
\text { Satisfaction }\end{array}$ & $\begin{array}{r}\text { Providing } \\
\text { positive } \\
\text { words of } \\
\text { mouth. }\end{array}$ & .32 & .002 & .031 & .148 & .361 \\
\hline $\begin{array}{r}\text { E-banking } \\
\text { Satisfaction }\end{array}$ & - & $\begin{array}{r}\text { Providing } \\
\text { positive } \\
\text { words of } \\
\text { mouth. }\end{array}$ & .409 & & .000 & & .409 \\
\hline
\end{tabular}

Table 6 Results of the direct, indirect and total relationship of the study variables

The previous table Show that: There is not significant effect between (electronic communication channels) and providing positive words of mouth for others. Where the value of the beta coefficient was $p=(.674)$. There is a significant effect between (customization strategies) and providing positive words of 
mouth for others. Where the value of the beta coefficient was less than (0.05). The direct effect between (electronic communication channels, customization strategy) and providing positive words of mouth to others was found to be greater than the indirect effect between (electronic communication channels, customization strategy) and providing positive words of mouth to others. Which shows that banking eSatisfaction does not play the role of mediator in influencing the relationship between E-CRM dimensions and providing positive words of mouth to others. And thus, reject the sub- hypothesis (the third and the four) of the third main hypothesis.

\section{Discussion and Conclusion}

Electronic communication channels such as Internet Banking have helped customers reduce the cost of obtaining information about the Bank's services, inquiring about bank balance, conducting transactions via bank phone, using e-mail to receive any urgent notices, various schemes and policies of the Bank (Abu-Shanab et al. 2015), Enable customers to connect to their banks from anywhere, anytime and get complete and up-to-date personal information and services quickly, easily and at low cost (Darabi, Maroofi, and Torabi, 2012).

Although there are much literature on the relationship between e-CRM and customer E-loyalty, but academic researchers did not give enough attention to the role of Customer satisfaction for electronic banking services as a moderating variable between e-CRM and customer E-loyalty. Building customer Eloyalty still a vital strategy to continue and success of commercial banks in current highly competitive .our study has found that Customer satisfaction for electronic banking services does not mediate the relationship of dimensions E-CRM (electronic communication channels, customization) and providing positive words of mouth to others. And intentions to repeat e-dealing. which corroborates with previous research (Mang'unyi et al. 2018) unlike in previous studies (Alhaiou, 2011) that sees that E-satisfaction mediated the relationship between e-CRM and e-loyalty. We conclude that the loyal customers are not necessarily satisfied (poon, 2008).

Also, the study found that there is a significant relationship between the provision of commercial banks electronic channels of communication and the intent of repeated electronic transactions. supports the seminal research (Alim et al. 2014), who emphasized that contact interactivity is one of the key features of E-CRM that affects customer loyalty in UK mobile phone companies, and (Mogharabi et al. 2014) shows that the most dimensions of E-CRM for attracting new customers via the Internet is electronic communication channels. The study found that there is not significant relationship between the provision of commercial banks electronic channels of communication and provide customers with positive words of mouth on the deal with the bank. Similarly, Rahimiparvar, (2012) who deems there is a weak correlation between online communication channels and customer loyalty for online shopping in Thailand. Therefore, the first contribution to research is that The effectiveness of the electronic channels of communication in terms of enabling the customer to choose the electronic communication channels which he preferred to deal Through it (e-mail, SMS on mobile phone, personal messages on the customer's page via the Internet) and knowledge of the new information and services and policies followed by the bank, leads to providing customers with positive words of mouth about electronic transactions.

The study also found that there is not significant relationship between the Customization strategy followed by commercial banks and the intentions repeated to using online transaction and there is a significant relationship between the Customization strategy followed by commercial banks and provide customers with positive words of mouth about the electronic dealings with the bank. Thus, achieving customer E- loyalty, which corroborates with previous research (Mang' unyi et al. 2017) who stressed that customization, is the most influential factor of E-CRM pre-service customer loyalty. Similarly like in previous studies (Kassim et al. 2010) There is no relation between Customization and customer loyalty, so the second contribution to research is that the effectiveness of the customization strategy, in terms of (services customization or customization of relationships), in terms of summarizing user-related information (account balance, Debit and deposit operations, Time of installment payment, Deposits balances), and display this information on the customer's personal page. In order to enable the customer to complete the transactions, and Access to the Customized services for them according to their personal preferences, which leads to attracting customers to the website and then increase their satisfaction. The 
field study conducted by the researchers through interviews with customers of commercial banks that the arrangement of banking services available through the site of the bank leads to the completion of transactions easily and quickly, because increasing customer access on the bank's page causing pressure on the server, and thus slow the speed of the process of browsing. According the previous presentation, we can say the main contribution of the research is to enable commercial banks to create a large base of customers through the direct effect of E-CRM dimensions on customer E-loyalty.

\section{Managerial implications}

Customers are the factors which the banks are concentrating on them to success of online banking (Miremadi et al. 2012). So, this research study developed an understanding of the behavior of commercial banks customers who prefer electronic transactions. Through the study of e-loyalty precedents such as electronic communication channels and strategy of customize. In order to assess the importance of these precedents in enhancing the intentions of e-dealing with the bank and spread positive words of mouth to others. And Because of we have shifted from a transaction-based economy to a relationship-based economy, this study highlights the role of customization of relationships and services in achieve e-loyalty, the study concluded that commercial banks should customize online banking According to individual preferences to customers To promote e-loyalty. Similarly, Abu-Shanab et al. (2015) stressed that the allocation of e-banking services provides customers with convenience and reduced transaction costs, which has led customers to e-deal with the bank. For this reason, Rialti et al. (2017) are focused on that bank managers must be customize services according to the requirements of customers, and not to the advantages that managers believe that affect the satisfaction of customers. This finding agrees with the view that online marketers must be developing marketing offers suitable for a complex and diverse market (Kassim et al. 2010). However, it will not be enough for commercial bank managers to pay attention to designing marketing strategies that meet the needs of different customers to encourage them to repeat the e-transactions (behavioral aspect), or move their emotional aspects to urge others to experience the e-dealing, but also managers Continuous attention should be paid to the development of programs provided through various channels of communication, and the interest in the existence of continuous communication with customers through different channels of communication to find out the needs of customers and the extent of utilization of provided services. Since the use of electronic CRM techniques helps banks to communicate and interact with their customers, reduce the costs of reaching the right customer and provide the right banking service at the right time through the appropriate communication channels (Abu-Shanab et al. 2015). So This study contributes to the development of commercial banks' awareness towards the development of electronic communication channels in terms of increasing the number of ATMs and providing them with sufficient cash, minimizing the breakdowns of the current ATMs, in addition to activating the role of e-mail in terms of informing customers of the latest information, policies and new schemes that the Bank will achieve.

\section{Limitations and Trends of Future Research}

The research was limited to commercial banks only and therefore there is a need to confirm the results by future studies on investment banks and other financial institutions. The research was also limited to customers of commercial banks that deal electronically. Because it is widely believed that e-CRM performance should be measured in terms of customers Perceptions and behaviors as they are key source of value (Azila et al. 2012). And did not address the users and employees within the banks. Therefore, there is a need for further studies on the impact of CRM on e-loyalty from the perspective of Bank employees. The study was limited in the measurement dimensions of customization (customize of services and customize of relationships) and therefore must conduct future research to study the changing and different patterns of customer needs and desires.

\section{References}

Anderson, J. and Gerbing, W. (1988), "Structural equation modeling in practice: a review and Recommended two stage approach", Psychological Bulletin, Vol. 27, No.1, pp. 5-24. Arbuckle, J. (2013), Amos 22. User's Guide, Small waters Corporation, Chicago, IL.

Abu-Shanab, E. and Anagreh, L. (2015), Impact of electronic customer relationship management in banking Sector, International Journal of Electronic Customer Relationship Management, Vol. 9, No. 4. pp. 254-270. 
Amin, M. (2016),"Internet banking service quality and its implication on e-customer satisfaction and e-customer loyalty", International Journal of Bank Marketing, Vol. 34 Issues 3 pp. $280-306$.

Alim, S. and Ozuem, w. (2014), the Influences of e-CRM on Customer Satisfaction and Loyalty in the UK Mobile Industry, Journal of Applied Business and Finance Researches, Vol. 3 Issue 2: pp. 47-54.

Alhaiou, T. A. (2011), A Study on the Relationship between e-CRM Features and E-Loyalty: The Case in UK. Unpublished PhD thesis, Brunel Business School, Brunel University, West London. Retrieved 24 April 2016 from http:/ / www.core.ac.uk/download/pdf/1440953.pdf.

Al-Hawary, S.I.S. and Hussien, A.G.A. (2017) the Impact of Electronic Banking Services on the Customers Loyalty of Commercial Banks in Jordan, International Journal of Academic Research in Accounting Finance and Management Sciences, vol. 7, No1, pp. 50- 63.

Azila, N. and Noor, M. (2012) 'trust and commitment: do they influence e- customer relationship Performance? International Journal of Electronic Commerce Studies, Vol.3, No.2, pp. 281-296.

Azila, N. and Noor, M. (2011) 'Electronic customer relationship management performance: its Impact on loyalty from customers' perspective', International Journal of e-Education, E-Business, e-Management and e-Learning, Vol. 1, pp.1-6.

Belás, J., Chocholáková, A., Gabčová, L. (2015), Satisfaction and loyalty of banking customers: A gender approach, Economics and Sociology, Vol. 8, No 1, pp. 176-188. DOI: 10.14254/2071- 789X.2015/8-1/14.

Bagozzi, R.P. and Yi, Y. (1988), "On the evaluation of structural equation models", Journal of The Academy of Marketing Science, Vol. 16 No. 1, pp. 74-94.

Cook, J. D., Hepworth, S. J., Wall, T. D., \& Warr, P. B. (1981). The experience of work. San Diego: Academic Press.

Darabi, A., Maroofi, F. and Torabi, J. (2012) 'Effects of E-CRM on customer-bank Relationship Quality and result', International Journal of Academic Research in Accounting, Finance and Management Sciences, Vol. 2, pp.164182.

Dhingra, M. and Dhingra, V. (2013), “Determinants of electronic customer relationship Management (E-CRM) for customer satisfaction in banking sector in India", African Journal of Business Management, Vol. 7, pp. 762-768.

El Essawi, N. and Abd El Aziz, R. (2012), determining the main dimensions that affect e-customer Relationship management readiness in the Egyptian banking industry, Int. J. Electronic Customer Relationship Management, Vol. 6, Nos. 3/4.

Faraoni, M., Rialti, R., Zollo, L and Pellicelli, A.C. (2018) "Exploring e-Loyalty Antecedents in B2C e-Commerce: Empirical results from Italian grocery retailers", British Food Journal, https://doi.org/10.1108/BFJ-04-20180216.

Fornell, C. and Larcker, D.F. (1981), "Evaluating structural equation models with unobservable Variables and Measurement error", Journal of Marketing Research, Vol. 18, pp. 39-50.

Farhadi, F., Ghartemani, S.K., Ghartemani, H.K and Wastegany, J.R. (2012), Analyzing the Effects of e- CRM on customers Loyalty: Acase study of Parsmodir Khazar Enterprise, Advanced Research in Economic and Management Sciences (AREMS) Vol.7

Farnad, F and Afghah, Z.S, (2017), Effect of E-CRM System on Attracting Bank Deposits, International Journal of information security and system management, Volume6, Number1, pp6.

Gremler, D.D., (1995), the effect of satisfaction, switching costs, and interpersonal bonds on Service loyalty Doctoral Thesis. Arizona State University.

Herington, C. and Weaven, S. (2009), "E-retailing by banks: e-service quality and its importance to customer satisfaction", European Journal of Marketing, Vol. 43 No 9/10, pp. 1220-1231.

Ho, C.-T.B. and Lin, W.-C. (2010), "Measuring the service quality of internet banking: scale Development and validation", European Business Review, Vol. 22 No. 1, pp. 5-24.

Hair, J.F., Black, W.C., Babin, B.J. and Anderson, R.E. (2010), Multivariate Data Analysis: A Global Perspective, Pearson Prentice Hall, New York, NY.

Harrigan, P., Ramsey, E. and Ibbotson, P. (2012), “Entrepreneurial marketing in SMEs: the key Capabilities of eCRM", Journal of Research in Marketing and Entrepreneurship, Vol. 14 No. 1, pp. 40-64

Hosseinianzadeh, M. (2015), A Framework for e-CRM Implementation in Health Service Industry of a Developing Country, International Journal of Engineering and Innovative Technology (IJEIT) Volume 4, Issue 8.

Ismail, M.A, and Safa N.S. (2014), Trust, Satisfaction, and Loyalty Formation in Electronic Commerce, Journal of Industrial and Intelligent Information Vol. 2, No. 3.

Keshvari, R. (2012) 'The impact of E-CRM on customers attitude and its association with Generating competitive advantage in Iranian financial B2B context', International Business Research, Vol. 5, pp.34-54.

Kassim, N. and Abdullah, N.A. (2010), the effect of perceived service quality dimensions on Customer satisfaction, trust, and loyalty in e-commerce settings: Across cultural Analysis, Asia Pacific Journal of Marketing and Logistics, Vol. 22 Issues : 3 pp. 351 - 371 DOI 10.1108/13555851011062269 
Khan, M.B and Khawaja, K.F. (2013), the Relationship of E-CRM, Customer Satisfaction and Customer Loyalty. The Moderating Role of Anxiety, Middle East Journal of Scientific Research, vol. 16 pp. 531-535.

Khaligh, A., Miremadi, A and Aminilari. M, (2012), The Impact of E-CRM on Loyalty and Retention of Customers in Iranian Telecommunication Sector, International Journal of Business and Management, Vol. 7, No. 2.

Levy, S. (2014), “Does usage level of online services matter to customers' bank loyalty? Journal of Services Marketing, Vol. 28 No. 4, pp. 292-299.

Lee, M.L. (2005), "the impact of perceptions of interactivity on customer trust and transaction Intentions in mobile commerce", Journal of Electronic Commerce Research, Vol. 6 No. 3, pp. 165-80.

Liu, C, Tseng, H., Chuang, L. and Huang, C, (2012), A Study of the Impact of the e-CRM Perspective on Customer Satisfaction and Customer Loyalty-Exemplified by Bank Sinopac, Journal of Economics and Behavioral Studies, Vol. 4, No. 8, pp. 467-476.

Lam, A.Y.C., Cheung, R. and Lau, M.M, (2013), the Influence of Internet-Based Customer Relationship Management on Customer Loyalty, Contemporary Management Research, Vol. 9, No. 4, pp. 419- 440.

Michal, D and Stverka, I (2001), E-CRM Makes One-to-One Theory a Reality. Sys Integ; p. 103

Miremadi,A. R, Ghalamakri, S and Ramezani,A.A,(2012) Challenges in Trust and Security by Implementation of ECRM among Banks and Financial Institution: A Case Study Of E-Banking in Iran,International Journal of Information Science and Management, Special Issue.

Mulyono, H. and Situmorang, S.H. (2018), E-CRM and loyalty: A mediation Effect of Customer Experience and satisfaction in online transportation of Indonesia, Acadimac Journal of Economic studies, vol. 4, No. 3, pp. 96105.

Mang' unyi, E. E., Khabala, T. O. and Govender, K. K. (2017), “The relationship between e-CRM And customer loyalty: a Kenyan commercial bank case study", Bank and Bank Systems,Vol. 12 No. 2, pp.106-115, http://dx .do i.org/10.21511/bbs.12(2).2017.11.

Mang'unyi, E .E., Khabala, T.O. and Govender, K.K (2018), "Bank Customer Loyalty and Satisfaction: The Influence of Virtual e-CRM", African Journal of Economic and Management Studies, https://doi.org/10.1108/AJEMS-082017-0183.

Mogharabi, V., Akbarabadi, L., Mirnezhad,R. and Kariznoee, A.(2014), Examining the role of Electronic Customer Relationship Management (E-CRM) on Attracting Customers In Internet Marketing, interdisciplinary Journal of contemporary Business Research, vol 5, No 10.

Nunnally, J.C. (1978), Psychometric Theory, Vol. 2, McGraw-Hill, New York, NY.

Noor, (2018), E-loyalty in digital platforms - How do the employees in banks experience their Work with customer eloyalty, individually and in relation to each other? Master Thesis, spring, Uppsala University.

Ocker, R. and Mudambi, S. (2002) 'assessing the readiness of firms for CRM: a literature review and research model', Proceedings of the 36th Hawaii International Conference on System Sciences (HICSS'03). 4, pp. 674-696, doi: 10.1515/mmcks-2017-0039.

Poon, W. (2008), Users' adoption of e-banking services: the Malaysian perspective, Journal of Business and Industrial Marketing, Vol. $23 \cdot$ NO 1, PP 59- 69.

Palmer, J.W. (2002) Web site usability, design, and performance metrics, Information Systems Research; 13(2): PP 205223.

Peikari, H.R. (2010), the Influence of Security Statement, Technical Protection, and Privacy on Satisfaction and Loyalty; A Structural Equation Modeling, Springer, pp., 223-231.

Pensiri, P. (2011), the use of E-CRM, Can Enhance the Customer Relationship in Toyota Mahanakorn, Master Thesis.

Rialti, R., Zollo, L., Pellegrini, M.M. and Ciappei, C. (2017), "Exploring the antecedents of brand Loyalty and electronic word of mouth in social-media-based brand communities: do Gender differences matter?", Journal of Global Marketing, Vol.30 No. 3, pp. 147-160.

Romano, N.C. and Fjermestad, j. (2003), Electronic Commerce Customer Relationship Management: A Research Agenda, Information Technology and Management, vol. 4, pp. 233-258, DOI: 10.1023/A: 1022906513502.

Ribbink, D., van Riel, A.C.R., Liljander, V. and Streukens, S. (2004), "Comfort your online Customer: quality, trust, and loyalty on the internet", Managing Service Quality, Vol. 14 No. 6, pp. 446-56.

Ramseook-M., P. and Naidoo, P. (2011), "Customers' perspectives of service quality in internet Banking", Services Marketing Quarterly, Vol. 32 No. 4, pp. 247-264.

Rao, J.P. (2013) 'Impact of socio-economic characteristics of the bank customers on CRM', Tactful Management Research Journal, Vol. 1, pp.1-8.

Rahimiparvar, N. (2014). E-CRM features that affect customer attitude to loyalty: a case study of University students enrolled in international programs in Thailand. GSBE Journal, 36-51. Retrieved 28 March 2017 from www.graduate.au.edu/gsbejournal/Journals/Dec2014/Journal03.pdf

Rosário, J. d. (2015) E-loyalty in e-commerce: A study at girissima.com, doctoral Thesis. 
Sivaraks, P, Krairit, D and Tang, J.C.S, (2011), Effects of e-CRM on customer-bank relationship Quality and outcomes: The case of Thailand, Journal of High Technology Management Research, vol 22, pp 141-157, doi:10.1016/j.hitech.2011.09.006.

Saini, G. S. and kumar, S, (2015), The Effect of e-CRM on Customer Satisfaction: Empirical Study of Online Shopping, Journal of Management and Science, Vol.5, No.2.

Sunny, E.E, and Abolaji, O.S, (2016), Electronic Customer Relationship Management (E-CRM) \& Marketing Performance: Empirical Evidence from Nigeria Telecom Sector, British Journal of Economics, Management \& Trade, vol11, No (1),pp: 1-14.

Shastri, S, Rathore, J.S. and Sharma, R (2018), Effect of E-CRM ON Customer's Satisfaction \& Evident from Indian Banking websites, ELK Asia Pacific Journal of Marketing and Retail Management, Vol9, ISSN 2349-2317.

Ski, (2016), Svenskt Kvalitetsindex Bank 2016. SKI. September 3rd.http://www.kvalitetsindex.se/report/bank- och-finans-2016.

Valvi, A.C, West, D. C, (2013) E-loyalty is not all about trust, price, also matters: extending Expectation- confirmation theory in book selling web sites, Journal of Electronic Commerce Research, vol 14, No 1.

Zeithaml V, A., Parasuraman, A. and Malhotra, A. (2002), "Service quality delivery through Websites: a critical review of extant knowledge", Journal of the Academy of Marketing Science, Vol. 30 No. 4, pp. 362-75.

Zatalini, M.A. and Pamungkas, T.N (2017), exploring the success factors of E-CRM Implementation on B2C Ecommerce: satisfaction and loyalty conceptual Framework, Journal Economy business Volume 22, No.2.

Zeithaml, V.A., L.L. Berry and A. Parasuraman, (1996)"The Behavioral Consequences of Service Quality," Journal of Marketing, Vol. 60, No. 2:31-46.

\section{Appendix A}

NO

channels:

Customization:

Electronic

Satisfaction:

\section{Questionnaires}

Internet banking:

-The online banking is prompt in replying to queries

-The online banking is prompt in replying to requests.

-The customers can access their account and order service information via Internet.

ATMs:

-The spread of ATMs in several geographical areas.

- ATM platform designed to enable the completion of banking transactions easily.

- Adequate cash is always available at ATMs.

- Service not available for long periods in ATMs.

e-mail:

- You receive new advertisements for the bank by email.

- Through e-mail you can know the new policies and plans of the bank.

-I feel my personal needs have been met when using the site or doing transactions with the online banks.

-I feel the online banking has the same norms and values as I have.

-This site provides me with information and products according to my preferences.

-This site provides me with information on how to do the products modification according to my preferences.

Banking -I am generally pleased with the Banking's online services.

-I am very satisfied with the Banking's online services.

-I am happy with the online Banking.

-The website of the online Banking is enjoyable. references

(Ribbink et al. 2004; Ocker et al. 2002)

(Abu-Shanab et al. 2015.

Al-Hawary et al. 2017)

(Al-Hawary et al. 2017.

Lam et al. 2013.

Rao, 2013)

(Herington et al. 2009.

Ho et al. 2010)

(Herington et al. 2009.

Ribbink et al. 2004) 
-The website of online banks is simple to use. -I am satisfied with overall online bank's products and services.

E-Loyalty: Intentions dealing:
-I seldom consider switching to another Web site.

to Repeat EEwould switch Web sites.

-I try to use the Web site whenever I need to make a purchase.

-When I need to make a purchase, this Web site is my first choice.

-I like using this Web site.

-I intend to continue using the online Banking.

-I prefer the online Banking above others.

Provide positive words of -I would recommend the Bank's website to others mouth

to others:
-I would like to say positive things about online banking to other people

-I would recommend online banking to someone who seeks advice
(Gremler, 1995; Zeithaml et al. 1996; Ribbink et al. 2004)

(Ribbink et al. 2004.

Ramseook et al. 2011; Zeithaml et al. 1996) 